\title{
Cytokines and apoptosis in atopic dermatitis
}

\author{
Łukasz Szymański ${ }^{1}$, Aleksandra Cios $^{2}$, Martyna Ciepielak², Wanda Stankiewicz ${ }^{2}$
}

${ }^{1}$ Department of Molecular Biology, Institute of Genetics and Animal Biotechnology, Polish Academy of Science, Magdalenka, Poland ${ }^{2}$ Department of Microwave Safety, Military Institute of Hygiene and Epidemiology, Warsaw, Poland

Adv Dermatol Allergol 2021; XXXVIII (1): 1-13

DOI: https://doi.org/10.5114/ada.2019.88394

\begin{abstract}
Atopic dermatitis (AD) is the most common chronic inflammatory skin disease. AD affects $10-20 \%$ of children worldwide and persists into adulthood in a minority of cases, affecting approximately $2-3 \%$ of the adult population, with an increased prevalence over the past decades in developed countries. Atopy is a genetic tendency to overproduce lgE class antibodies in response to common antigens found in the environment. Concurrence of different atopy such as allergic rhinitis or asthma in children with $A D$ is estimated at $80 \%$. AD is characterized by a vicious cycle of an allergic immune response. The emerging picture of the $A D$ is a complex disorder with barrier dysfunction, immunological, genetic and environmental factors all playing key roles. Patients with severe or persistent disease and their families experience significant impairment in their quality of life, and in addition, AD places a heavy economic burden on society as a whole. Pathogenesis, the role of the epidermal barrier, mechanisms of cells apoptosis, the role of T cells and cytokines in $A D$ are discussed in this article.
\end{abstract}

Key words: atopic dermatitis, apoptosis, cytokines, T cells.

\section{Introduction}

Atopic dermatitis (AD) affects $10-20 \%$ of children worldwide and persists into adulthood in a minority of cases, affecting approximately $2-3 \%$ of the adult population, with an increased prevalence over the past decades in developed countries. Atopy is a genetic tendency to overproduce IgE class antibodies in response to common antigens found in the environment. Concurrence of different atopy such as allergic rhinitis or asthma in children with $A D$ is estimated at $80 \%[1,2]$. AD is characterized by a vicious cycle of an allergic immune response. Disrupted skin barrier due to biological or genetic factors, induces production of inflammatory cytokines from keratinocytes, which enhances the allergic immune response. Itch induced by the allergic immune response triggers scratching, which exacerbates skin barrier dysfunction. Pruritus is a major symptom of AD which impacts the quality of patient's life to a great extent. Patients with severe or persistent disease and their families experience significant impairment in their quality of life [3], and in addition, $A D$ places a heavy economic burden on the society as a whole [4].

Previously there were two major competing hypotheses regarding the pathogenesis of AD. The inside-out hypothesis which stated that $A D$ is a result of the imbalance in the adaptive immune system that affects the skin barrier by creating a cutaneous inflammatory state and leads to its impairment. In this theory, barrier disruption is caused by a number of factors such as itching, caused by highly expressed IL-31RA, which leads to scratching [5] and thus, higher penetration of allergens, more abundant Staphylococcus aureus presence caused by immune imbalance [6], and downregulated filaggrin production in the skin [7]. More recently, AD has been linked to mutations and polymorphisms in IL-10 and IL-13 genes [8], which also strengthened this theory.

The outside-in hypothesis suggested that skin barrier abnormalities occur first and trigger dysregulations in the immune system. This theory was strongly supported by a number of studies linking, on average, $20 \%$ of AD cases in Europe and Asia with null mutations in filaggrin gene FLG [9-11]. However, it is important to state that in Africa AD affects $15 \%$ of children [12] while less than $5 \%$ of residents of African descent have a mutated filaggrin gene. Filaggrin is paramount for proper function of the skin barrier because of its role in the release of the natural moisturizing factor (hygroscopic amino acids) and in the creation of cornified cell envelope during cornifica-

Address for correspondence: Martyna Ciepielak MS, Department of Microwave Safety, Military Institute of Hygiene and Epidemiology, 128 Szaserów St, Warsaw, Poland, e-mail: ciepielakmartyna@gmail.com Received: 15.03.2019, accepted: 29.06.2019. 
tion of keratinocytes [13]. Therefore, according to this hypothesis, unfunctional filaggrin leads to the disrupted skin barrier resulting in cutaneous inflammation caused by Th2 cells [14].

Over time it became clear that the pathophysiological concepts underlying the development of $A D$ are multifactorial and include activation of different lymphocyte subsets, multi-cytokine immune dysregulation, epidermal barrier disruption, and microbiome imbalance. Skin barrier disruption or immunologic abnormalities may be more abundant at first in one AD patient than in another, but it is clear that those irregularities are simultaneously responsible for pathogenesis of atopic dermatitis [15].

\section{Acute and chronic atopic dermatitis}

Atopic dermatitis is a common allergic skin disorder characterized by a chronic relapsing form of skin inflammation, disturbance of epidermal barrier function that leads to dry skin, and keratinocyte apoptosis as a mechanism of eczema and spongiosis formation, which is mostly seen in acute and subacute lesions. The pathogenesis of AD is multifactorial, including genetic, environmental, skin barrier, physiological and immunological factors. Acute AD skin lesions are intensely pruritic, erythematous papules associated with excoriation and serous exudation. There is a marked infiltration of CD4+ T cells, CD8+ T cells, eosinophils, mast cells and dendritic cells [1]. Chronic AD skin lesions are characterized by tissue remodelling caused by chronic inflammation. The skin lesions are associated with thickened plaques, increased collagen deposition in the dermis, and dry fibrotic papules. Macrophages dominate the dermal mononuclear cell infiltrate. Eosinophils also contribute to the inflammatory response and T cells remain present, although in smaller numbers than seen in acute $A D$ $[1,2,16]$. During AD, resident structural elements of the skin (keratinocytes, fibroblasts, endothelial cells) closely interact with cells that are actively recruited from the blood in response to inflammatory stimuli. Complex cytokine and chemokine environment controls recruitment of $T$ cells from the blood vessels into the skin. During the early stages, keratinocytes produce cytokines and chemokines after mechanical trauma and skin barrier disruption $[1,2,16]$. This is reflected clinically by the itchscratch cycle, which may represent the initial point for starting an inflammatory reaction. Keratinocytes start to produce IL- $1 \alpha / \beta$, TNF- $\alpha$, IL- 8 and CCL2/MCP- 1 . This leads to infiltration of $T$ cells and monocytes and production of further keratinocyte-derived chemokines and cytokines. The local response of keratinocytes together with a reaction of endothelial cells, T cells, mast cells, macrophages, eosinophils, and dendritic cells finally leads to the characteristic clinical and histological appearance of AD. The generalized Th2-deviated immune response is usually linked to $A D$, however, the skin disease itself is a bipha- sic inflammation with an initial Th2 phase and a chronic Th1 phase $[1,16]$. A predominant systemic Th2 cytokine response with increased IgE levels and eosinophilia is widely accepted as a part of the AD pathogenesis. IL-4, IL-5, IL-13, and IL-31 are major Th2 cytokines that participate in $\mathrm{AD}$ and in other allergic disorders. IL-4 and IL-13 have essential roles in the initial phase of tissue inflammation and in the increased expression of adhesion molecules on endothelial cells $[2,16]$. Both cytokines are also responsible for the differentiation of allergen-specific Th2 cells and the class switching of activated B cells to IgE-producing cells. IL-5 contributes to the increase and survival of eosinophils $[2,16]$. The epidermis with atopic inflammation contains 2 distinct types of dendritic cells including the classical Langerhans cells and the inflammatory dendritic epidermal cells [17]. The latter population induces Th1 cytokines, whereas the Langerhans cell population induces Th2-type reactions [18]. The balance of these populations may induce Th2/Th1 cytokine profile switching characteristic of the chronic phase of AD. Acute AD skin lesions are characterized by T cells and eosinophils with deposition of eosinophil-derived products and increase skin expression of Th2 cytokines IL-4, IL-5, IL-13 and IL-31 with only little interferon- $\gamma$ (IFN- $\gamma$ ) expression $[16,17,19]$. Accumulation of activated monocytes, mature dendritic cells, and eosinophils determines a rise in IL-12 expression, appearance of Th2/Th1 switch and the presence of IFN- $\gamma$ in chronic AD lesions [19]. The processes occurring in acute and chronic AD are presented in Figure 1.

\section{Apoptosis in atopic dermatitis}

Upregulation of Fas by IFN-g sensitizes keratinocytes to Fas-induced apoptosis by invading T cells with FasL expression [20]. IL-17 is an important component of allergic and inflammatory diseases. Infiltration of IL-17-producing T cells (Th17) is known to be also abundant in the acute AD skin lesions [21]. IL-17-producing T cells (Th17) are distinct from Th1 and Th2 cells and have roles in innate and adaptive immunity [22]. IL-17 is involved in inducing and mediating pro-inflammatory responses through upregulation of IL-8, CXCL10 and TNF- production by keratinocytes and fibroblasts [22]. The chemokines that recruit Th2 cells into inflammatory sites have been categorized as Th2 chemokines. Chemokines also control Th1 cell chemotaxis. CCL20/MIP-3a is an important Th1 chemokine responsible for the recruitment of CCR6-expressing immature dendritic cells and memory/effector $T$ cells into the dermis of atopic skin through CCR6 [23]. On the other hand, CXCL9, CXCL10, and CXCL11 recruit mainly Th1-type lymphocytes to the inflammatory sites [24]. Several studies have demonstrated that keratinocyte apoptosis is an important component of eczema and spongiosis in patients with $A D$ and is mediated through Fas/FasL.

Two major apoptosis signalling pathways have been discovered: receptor-ligand mediated pathway (extrinsic) 


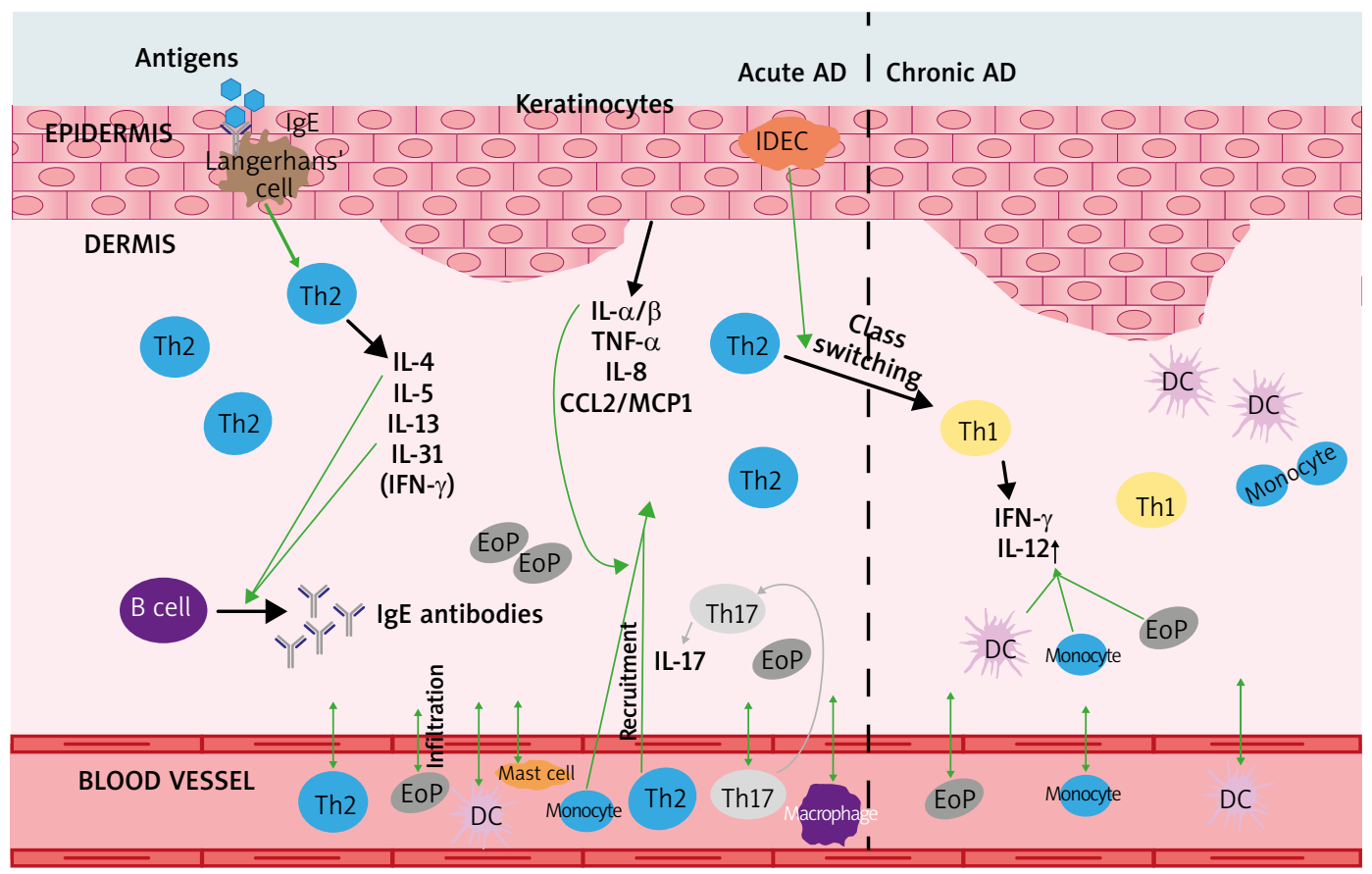

Figure 1. Acute and chronic stages of atopic dermatitis and representation of processes characteristic for each of them; IDEC - inflammatory dendritic epidermal cell, DC - dendritic cell, EoP - eosinophil

and mitochondrial-driven pathway (intrinsic). These pathways are regulated by a number of pro- and anti-apoptotic molecules. The extrinsic pathway is initiated by ligand binding to cell-surface death receptors (tumour necrosis factor receptor) superfamily (i.e. Fas, tumour necrosis factor, and tumour necrosis factor related apoptosis-inducing ligands: (TRAIL)-R1 and TRAIL-R2) [25]. Signalling via death receptors plays a crucial role in the activity of the immune system, where it contributes to the regulation of the adaptive immune response in various ways, most notably by triggering apoptosis of T cells [25]. Fas (CD95) receptor activates the apoptosis pathway upon binding to its physiological ligand FasL (CD95L). Fas is expressed on a variety of both lymphoid and non-lymphoid cells (e.g. liver, ovary, heart, lung, kidney, and skin). In contrast, FasL expression is limited to a few cell types (e.g. activated lymphocytes, some keratinocytes). The 'intrinsic' pathway involves a mitochondrial release of e.g. cytochrome c, AlF - apoptosis inducing factor, smac/DIABLO, which are released into the cytoplasm upon apoptosis induction triggered by cytotoxic drugs and DNA damage. The release of these pro-apoptotic factors is regulated by Bcl-2 family proteins forming homodimers and heterodimers that control mitochondrial membrane permeability. Some $\mathrm{Bcl}-2$ family proteins ( $\mathrm{BCl}-2$ and $\mathrm{Bcl}-\mathrm{xL}$ ) may block apoptosis whereas others (Bax, Bak, and Bid) promote apoptosis by interfering with these interactions [26]. Extrinsic and intrinsic apoptotic pathways are presented in Figure 2.
In normal skin, terminal differentiation of keratinocytes consists in a special form of apoptosis (cornification) which shows similarities between terminally differentiating keratinocytes and apoptotic cells; for example, granular keratinocytes show signs of endonuclease activation and DNA fragmentation [27]. Apoptosis in the skin represents a key event of the epidermal homeostasis. Its removes exceeding cells and guarantees the normal epidermal architecture, represents an important anticancer defence mechanism in response to UV radiation or oxidative damage [27]. Epidermal keratinocytes express Fas and FasL in low amounts [28]. Abnormal expression of lytically active FasL was found in inflammatory skin diseases such as toxic epidermal necrolysis, atopic dermatitis and allergic contact dermatitis [29]. After stimulation with pro-inflammatory cytokines such as IL-1 $\beta$, tumour necrosis factor $\alpha$ (TNF- $\alpha$ ), IFN- $\gamma$ and IL-15, but not IL-10, IL-12, TGF- $\beta$, keratinocytes express in a time- and dosedependent manner FasL [29]. Furthermore, there are several ways to trigger apoptosis in keratinocytes [29]: detachment of cells from tissue, triggering of the Fas receptor, activation of the perforin/granzyme B pathway, induction of genomic DNA damage, intracellular generation of ceramides catalysed by sphingomyelin hydrolase.

\section{Role of T cells in keratinocyte apoptosis}

Activated cytotoxic FasL+ T-cells are able to kill Fas+ keratinocytes. Cytotoxic T cells and Th1-cells express both 


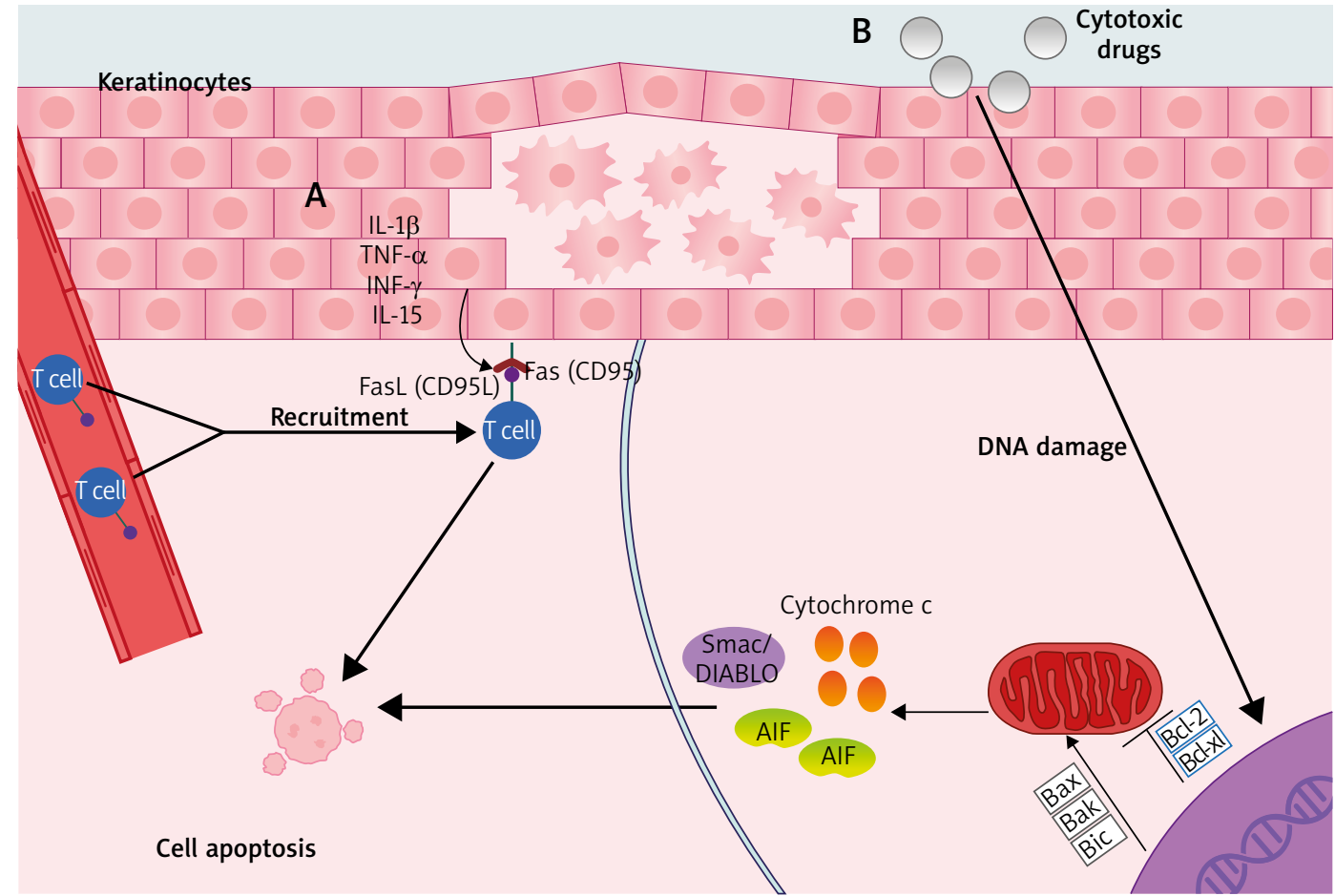

Figure 2. Apoptosis of keratinocytes in AD: A - Extrinsic (receptor-ligand mediated pathway), where stimulation of the keratinocytes by pro-inflammatory cytokines triggers the upregulated Fas receptor expression, while T cells are recruited from the blood vessel. FasL induces apoptosis through binding with FAS receptor. B - Intrinsic (mitochondrial-driven pathway), where apoptosis is induced by cytotoxic drugs and/or DNA damage, which stimulates mitochondria to release pro-apoptotic factors. This process is regulated by Bcl-2 family proteins; AlF - apoptosis-inducing factor

FasL and perforin, while Th2-cells do only express FasL. Cytotoxic T cells mainly use the perforin pathway, while Th2-cells act through FasL and Th1-cells inconstantly use both possibilities [25]. As mentioned, keratinocyte apoptosis is an important component of eczema and spongiosis in patients with AD [29]. Furthermore, IFN- $\gamma$-induced apoptosis occurs through Fas both in keratinocytes and IFN- $\boldsymbol{\gamma}$-producing $T$ cells. Although IFN- $\gamma$ appears to be a key factor, other cytokines, such as TNF- $\alpha$, TNF-like weak inducer of apoptosis (TWEAK), and IL-32, can also contribute to keratinocyte apoptosis in patients with $A D$ $[30,31]$. Emerging evidence indicates that Fas/FasL death receptors activate inflammatory or proliferative signalling via the prototypic proinflammatory transcription factor NF- $\kappa B$ or the mitogen activated protein kinase (MAPK) family of kinases [32]. Farley et al. demonstrated that FasL triggered an NF- $\kappa B$-dependent mRNA accumulation of inflammatory cytokines (TNF- $\alpha, I L-6$, and IL-1 $\beta$ ), chemokines (CCL2, CXCL1, CXCL3, and CXCL8/IL-8), and the adhesion molecule ICAM-1 in HaCaT cells and in reconstructed human epidermis (RHE) [33]. Activation of Fas was required both for apoptosis and for gene expression. Inhibition of caspase activity abolished FasL-dependent apoptosis; however, it failed to suppress the expression of FasL-induced genes [34]. Additionally, in the presence of caspase inhibitors, but not in their absence,
FasL triggered the accumulation of CCL5 (regulated on activation normal T cell expressed and secreted) mRNA. Furthermore, Farley et al. found that FasL-stimulated autocrine production of epidermal growth factor receptor (EGFR) ligands, and the subsequent activation of EGFR and ERK1 and ERK2 mitogen-activated protein kinases, were obligatory extracellular steps for the FasL-induced expression of a subset of inflammatory mediators [35]. Also, Krzyżowska et al. showed that murine keratinocytes stimulated with Fas cytotoxic antibody start to produce TNF- $\alpha$, CXCL10 and IL-1 $\beta[36,37]$. It is known that skin cell death receptors are expressed, but there is no evidence of extensive apoptosis of these cells, suggesting that non-apoptotic mechanism of Fas/FasL pathway is a commonly encountered phenomenon, although it has not been examined in the case of atopic dermatitis. Moreover, Farley et al. have previously shown that FasL induces production of secondary cytokines which trigger in keratinocytes the following inflammatory response this indicates the existence of an autoactivation loop of cytokines in the skin [33]. Thus, the Fas/FasL pathway may have a wider range of functions in the skin than previously suspected and may act as a potential starting point for further cutaneous inflammation.

Cytokines levels in atopic dermatitis have a significant impact on the course of the disease. Therefore, we 
shortly review the most important cytokines and their role in the pathogenesis of $A D$.

\section{Th1 cytokines}

\section{IL-12}

IL-12p70 cytokine is a heterodimer consisting of two subunits p35 and p40. It is produced by dendritic cells, macrophages, granulocytes, mast cells, and keratinocytes. IL-12p70 stimulates the proliferation, activation and cytotoxicity of T cells, and NK cells, as well as the production of cytokines such as IFN- $\gamma$ and TNF. In the chronic phase of AD, upregulated secretion of IL-12p70 is responsible for modulating the immune and inflammatory response, by stimulating the differentiation of Th0 cells into Th1-type [2, 38, 39].

\section{TNF}

TNF- $\alpha$ is one of the major immune response cytokines, primarily produced by not only stimulated monocytes and macrophages, but also keratinocytes [40]. The primary function of TNF is the regulation of the immune cells. It enhances the cytotoxicity of macrophages and monocytes, activates neutrophils and has chemotactic properties. TNF stimulates the production of reactive oxygen species and various cytokines (e.g., IL-1 and IL-6), induces inflammation and inhibits oncogenesis. TNF is an activator of the NF- $\kappa \beta$ pathway and is itself regulated by this pathway [41, 42]. In atopic dermatitis, TNF- $\alpha$ together with IL-4, IL-13, and IL-31 induce intercellular oedema and promotes allergic inflammation in the skin. In addition, increased levels of TNF- $\alpha$ along with IL-31, in the atopic skin, affect the structure and composition of lipids [43].

\section{Th2 cytokines}

\section{IL-4}

IL-4 is a Th2-type cytokine primary produced by mitogen- or antigen-stimulated helper T-cells, natural killer T-cells, mast cells and basophiles. Scientific reports suggest that keratinocytes also produce IL-4, and dermatitis causes an increase in its production [44, 45]. IL-4 has many important functions, inter alia, induction of allergic reactions, stimulation of $B$ lymphocytes proliferation and IgE production, as well as induction of T-cells differentiation into Th2-type. IL-4 has a significant role in maintaining skin homeostasis and is inversely correlated to the production of the EDC gene that regulates the function of the epidermal barrier [46].

\section{IL-13}

IL-13 is an immunoregulatory Th2-type cytokine secreted primarily not only by stimulated Th2 lymphocytes, but also by CD8+ T cells, NK cells, mast cells and keratinocytes [44, 47]. IL-13 acts primarily on monocytes and stimulates the proliferation of activated B-cells. Regula- tion of the synthesis and release of IL-13 by the cells is complex and depends on the influence of IL-4, IL-12, IL-18, IFN- $\gamma$, IL-10, TGF, and TNF- $\alpha$ [48]. IL-13 is a key mediator of skin inflammation which results in dysfunction of the epidermal barrier: its concentration is significantly higher in the atopic skin compared to healthy skin, and elevated levels of IL-13 and IL-4 increase susceptibility to skin infections caused by Staphylococcus aureus [49-51].

\section{IL-31}

IL-31 is a cytokine from the IL-6 family primarily produced by activated Th2 type T cells. Binding of IL-31 to the cell surface receptor leads to activation of the MAP kinase and PI3K/AKT pathway. Depending on the concentration of the cytokine and cell type affected, IL-31 stimulates or inhibits cell proliferation. Furthermore, IL-31 may increase the secretion of proinflammatory cytokines and chemokines, as it happens in AD keratinocytes. Upregulated expression of proinflammatory cytokines and chemokines leads to the recruitment of T lymphocytes. Interestingly, a high expression of IL-31RA is observed on sensory neurons that are directly responsible for the itching sensation. Increased IL-31 concentrations in inflammatory areas in patients with atopic dermatitis may, as with IL-4 and IL-13, lead to increased susceptibility to skin infections caused by Staphylococcus aureus [52, 53].

\section{Other cytokines}

\section{IL-1}

$\mathrm{IL}-1 \beta$ is one of the main regulators of the immune and inflammatory response, which affects almost all kinds of cells through IL-1RI. Moreover, IL-1 1 is a MAP kinase and $N F-\kappa \beta$ transcriptional factor agonist, which leads to the production of IL-6 [54]. In AD, the release of IL-1 $\beta$ from the epidermis is the first event following allergen activation. It increases the expression of adhesion molecules on endothelial cells, which facilitates the formation of proinflammatory and immunocompetent cells infiltration [55].

\section{IL-10}

IL-10 is an anti-inflammatory cytokine, mainly produced by stimulated T cells, B lymphocytes, macrophages, monocytes, and keratinocytes. It inhibits the cell-type immune response and inflammatory response. However, studies suggest that IL-10 also has immunostimulatory properties, with the function of eliminating infectious and allergic agents with limited inflammation. Numerous in vitro studies conducted in murine models and expression analysis of patients showed a significant effect of IL10 on the course of inflammatory, cancer and autoimmune diseases [56]. Among researchers investigating keratinocytes, there is an ongoing debate about the secretion of IL10 by keratinocytes derived from patients with $\operatorname{AD}[45,57]$. 


\section{IL-8}

IL-8 (CXCL8) is a proinflammatory chemokine secreted by many types of cells, including keratinocytes. The main function of IL-8 is the induction of neutrophil chemotaxis as well as the stimulation of their bactericidal properties. Furthermore, CXCL8 stimulates keratinocyte proliferation [58]. Activation of the Fas/FasL pathway results in the in creased secretion of IL-8 by these cells $[59,60]$.

\section{IL-17}

IL-17 is a cytokine produced by activated CD4+ T-cells. It is extremely pleiotropic, affecting (stimulating) many types of cells, including epithelial cells, endothelial cells, fibroblasts, and macrophages. Also, IL-17 induces maturation of dendritic cells and is involved in activation of $\mathrm{NF}-\kappa \beta$ transcription factor in the target cells [61]. Furthermore, IL-17 via the TRAF4-ERK5 signalling cascade stimulates keratinocyte proliferation [62]. IL-17 plays a significant but not fully known role in AD, for example, Nograles et al. observed that IL-17 induces non-specific immune response [63]. Moreover, in the early stages of inflammation, IL-17A can induce and/or modify T-cell differentiation in the Th2 type [64]. One of the most important functions of IL-17 in atopic dermatitis is the induction of proinflammatory responses in keratinocytes by increas ing the expression of GM-CSF, IL-8, and TNF CXCL10 [65].

\section{IL-33}

IL-33 is a cytokine from the IL-1 family primary secreted by damaged endothelial and epithelial barrier cells, fibroblast-like cells and skin keratinocytes [66, 67]. IL-33's main function is to act as an alarmin - a molecule that activates the innate immune system [68]. IL-33 is exclusively recognized by the ST2 receptor, which is highly expressed on Th2 and ILC2s cells [69]. Binding of the IL-33 to ST2 receptor leads to activation of MAP kinases (ERK, JNK, and p38), and NF-KB, through the IL-1RAcP recruitment and heterodimer formation. Activation of the MAP kinases and NF-кB-dependent pathways promotes ST2 positive cells survival, proliferation and Th2 cytokine secretion (IL-4, IL-5, IL-13) [70]. In atopic dermatitis, IL-33 is released by the epithelium upon allergen exposure and leads to maturation, migration and promotes survival of the basophiles and mast cells [71]. What is more, anti-IL-33 antibody called ANB020 was shown to reduce EASI score and blood eosinophil levels in patients with moderate-to-severe adult atopic dermatitis in Phase-2a clinical trial [72].

\section{IL-19}

IL-19 is a proinflammatory cytokine from the IL-10 family, which is mostly secreted by monocytes, keratinocytes, and epithelial cells [73-75]. The main function of the IL-19 is to promote the production and secretion of Th2 cytokines. IL-19 is induced by IL-17A and is recognized by the IL-20R1 and IL-20R2 receptors and leads to activation of JAK and STAT3 pathways $[76,77]$. In atopic dermatitis, IL-19 is highly expressed in the skin lesions. Interestingly, keratinocytes secrete IL-19 as well as express IL-20R1 and IL-20R2 receptors suggesting that IL-19 can act in an autocrine manner. Finally, it was shown that the IL-19 amplifies the IL-17A effects in keratinocytes [78].

\section{Current research regarding cytokines in AD}

The analysis of scientific literature, summarized in Table 1, revealed that the majority of research does not have an established and unified research methodology or research material. Results obtained from in vitro cell studies are not reflected in blood tests or biopsy samples. The most popular cytokines tested are IL-8, IL-10, IL-13, IL-19, and IL-17.

Fairly consistent results can be found for IL-8 which was upregulated in AD derived mesenchymal stem cells when compared with healthy controls [79]. What is more, Yang et al. showed strong upregulation of IL-8 in AD skin lesions, which was inversely correlated with miR-124 [80]. Also, IL-10 despite being predominantly tested in the blood [81-83] appears to be reflected in biopsy specimens where its level is also upregulated [84], particularly in pruritic atopic skin lesions [85].

IL-13 mRNA expression level is elevated mainly in eczema lesions [86]. A high level of IL-13 was observed both in the lesional biopsy in adults [87] and in children [88]. Cell and biopsies studies also show that IL-13 mRNA level can be reduced by using steroids [85] or after ustekinum$a b$ treatment [89]. Although the results of blood cytokine levels vary in different studies, it can be confirmed that the level of IL-13 in blood collected from AD patients is higher when compared to psoriasis [90, 91]. Similar results were obtained for IL-19 [79, 86, 89] however, the level of IL-19 was significantly higher in children biopsies when compared to adults [88].

In the last few years, IL-17 is the most widely studied, especially subtype A. IL-17A was upregulated in AD-derived mesenchymal stem cells [79], TDP cells [92] as well as in biopsy lesions of an itchy AD [93] and conventional psoriasis [86]. Just like IL-19, IL-17A expression level was higher in children when compared to adults. However, Martel et al. was unable to detect the IL-17A or IL-17F in supernatants of cell cultures derived from either intrinsic or extrinsic $A D$ [94].

\section{Conclusions}

In AD, the inside-out hypothesis has been favoured over the outside-in hypothesis, until mutations in genes encoding skin barrier proteins were discovered. According to the outside-in hypothesis, the skin barrier impairment, mainly linked to filaggrin mutations, is the main pathogenic factor in AD. However, most of the patients that have filaggrin mutations do not develop AD and only 
Table 1. Analysis of scientific literature regarding atopic dermatitis

\begin{tabular}{|c|c|c|}
\hline $\begin{array}{l}\text { Author, year } \\
\text { of publication }\end{array}$ & Material & Main findings \\
\hline $\begin{array}{l}\text { Chen et. al., } \\
2016 \text { [95] }\end{array}$ & $\begin{array}{l}\text { Human T helper cell line } \\
\text { Jurkat and } 293 T\end{array}$ & $\begin{array}{l}\text { In Jurkat cells overexpressing miR-151a, the following was noticed: } \\
\text { - decreased expression levels of IL-2, IL-12, and IFN- } \gamma \\
\text { - downregulation of IL12RB2 which expression was regulated by miR-151a by } \\
\text { targeting two loci in the 3' untranslated region of the IL12RB2 gene }\end{array}$ \\
\hline $\begin{array}{l}\text { Brunner } \\
\text { et. al., } 2017 \\
{[84]}\end{array}$ & $\begin{array}{l}59 \text { patients with moderate-to- } \\
\text { severe } A D \text { ( } 31 \text { male and } \\
28 \text { female patients), } \\
20 \text { patients reported to have } \\
\text { mild asthma, of which } \\
11(18.6 \%) \text { were on asthma } \\
\text { treatment (inhaler); } 9 \text { patients } \\
(16.1 \%) \text { reported seasonal } \\
\text { allergies }\end{array}$ & $\begin{array}{l}10 \text { increased proteins in serum of both diseases: IL-16, IL-17C, IL-2RA, TNF, and IFN } \\
\text { AD patients showed increased level of: } \\
\text { - T-cell development/activation (IL-7, IL-2RB, IL-15RA) } \\
\text { - Th2 (IL-13, IL-10, IL-10RB), Th1, Th1/Th17/Th22 (IL-12/IL-23p40), and IL-17 responses } \\
\text { in serum consistent with skin expression } \\
\text { AD inflammatory mediators (e.g. IL-12/IL-23p40) correlated between blood and } \\
\text { lesional and non-lesional skin } \\
\text { In psoriasis, TNF-R2, IL-17A, IL-6, IL-1RA, and IL-1RL1 were upregulated } \\
\text { Multiple inflammatory pathways showed stronger enrichment in AD than psoriasis } \\
\text { Several atherosclerosis mediators in serum (e.g. IL-16) correlated with SCORAD, but } \\
\text { not BMI } \\
\text { Pathways exclusively enriched in AD included: cytokines and inflammatory } \\
\text { responses, T1/T2 differentiation, dendritic cell pathway, asthma, IL-12 STAT4 } \\
\text { signalling, CD40L signalling, IL-4 signalling, and CXCR3 signalling, IL-2 STAT5 } \\
\text { signalling, CD8+T-cell signalling, and TCR signalling } \\
\text { Pathways exclusively enriched in psoriasis included: HIF1- } \alpha \text { transcription factor } \\
\text { network, AMB2 neutrophils pathway, NK-cell mediated cytotoxicity, ceramide } \\
\text { signaling, and innate immune system (Reactome) }\end{array}$ \\
\hline $\begin{array}{l}\text { Weiss et al., } \\
2017 \text { [89] }\end{array}$ & $\begin{array}{l}3 \text { patients with severe } A D \\
\text { who were administered } 45 \mathrm{mg} \\
\text { of subcutaneous ustekinumab } \\
\text { over a period of } 16 \text { weeks }\end{array}$ & $\begin{array}{l}\text { Decrease: } \\
\text { - in IL-12/-23 p40 in dermal mast cells and epidermal Langerhans cells } \\
\text { - in IL-13, IL-12/-23p40, IL-19, IL-22 mRNA levels after } 8 \text { weeks of ustekinumab } \\
\quad \text { treatment } \\
\text { Heterogeneous expression of IFN- } \gamma \text { and IL-17A, IL-23 p19 mRNA level }\end{array}$ \\
\hline $\begin{array}{l}\text { Orciani et al., } \\
2017 \text { [79] }\end{array}$ & $\begin{array}{l}\text { Mesenchymal stem cells } \\
\text { (MSCs) isolated from the skin } \\
\text { of } 12 \text { adult patients ( } 7 \text { male } \\
\text { and } 5 \text { female patients) with } \\
\text { chronic AD } \\
\text { The control group included } \\
12 \text { healthy white adults } \\
\text { (7 male and } 5 \text { females } \\
\text { patients) }\end{array}$ & $\begin{array}{l}\text { AD-MSCs showed: } \\
\text { - upregulation of IL-3, IL-6, IL-8, IL-12B, IL-13, IL-17A, IL-17F, and IL-21 } \\
\text { - downregulation of IL-2, IL-4, IL-5, and IL-23A } \\
\text { - normal regulation of IL-17C and TNF } \\
\text { - no significant differences among different samples } \\
\text { - no significant variations between C-MSCs and AD-MSCs } \\
\text { The results obtained by ELISA mostly reflected those found in the PCR analysis: } \\
\text { - IL-3, IL-17F, and IL-23A were normally expressed } \\
\text { - IL- 6, IL-8, IL-12, IL-13, IL-17A, IL-21, and TGF- } \beta \text { increased in AD-MSCs } \\
\text { - IL-2, IL-4, and IL-5 were produced in lower amounts by AD-MSCs } \\
\text { - IL-17C, TNF- } \alpha \text { were similarly secreted by CMSCs and AD-MSCs }\end{array}$ \\
\hline $\begin{array}{l}\text { Yang et al., } \\
2017 \text { [80] }\end{array}$ & $\begin{array}{l}37 \text { paired atopic eczema skin } \\
\text { lesional tissues and normal } \\
\text { non-lesional tissues }\end{array}$ & $\begin{array}{l}\text { miR-124 expression was possibly downregulated by all the indicated inflammatory } \\
\text { factors (IL-13, IL-1ß, IL-17A, IL-4) and more strongly downregulated by IFN- } \gamma \text { and } \\
\text { TNF- } \alpha \\
\text { IL-8 mRNA expression was upregulated in chronic lesional skin of patients with } \\
\text { atopic eczema, and all inversely correlated with miR-124 }\end{array}$ \\
\hline $\begin{array}{l}\text { Moy et al., } \\
2017 \text { [96] }\end{array}$ & $\begin{array}{l}\text { Skin biopsies obtained } \\
\text { between } 2009 \text { and } 2014 \\
\text { (retrieved from the pathology } \\
\text { archives) } \\
\text { Psoriasis not treated with } \\
\text { TNF- } \alpha \text { inhibitors }(n=9) \\
\text { Psoriasis previously treated } \\
\text { with/unresponsive to anti- } \\
\text { TNF- } \alpha \text { therapy }(n=11) \\
\text { PsoD related to antiTNF- } \alpha \\
\text { treatment for another } \\
\text { underlying condition }(n=9) \\
\text { and AD }(n=9)\end{array}$ & 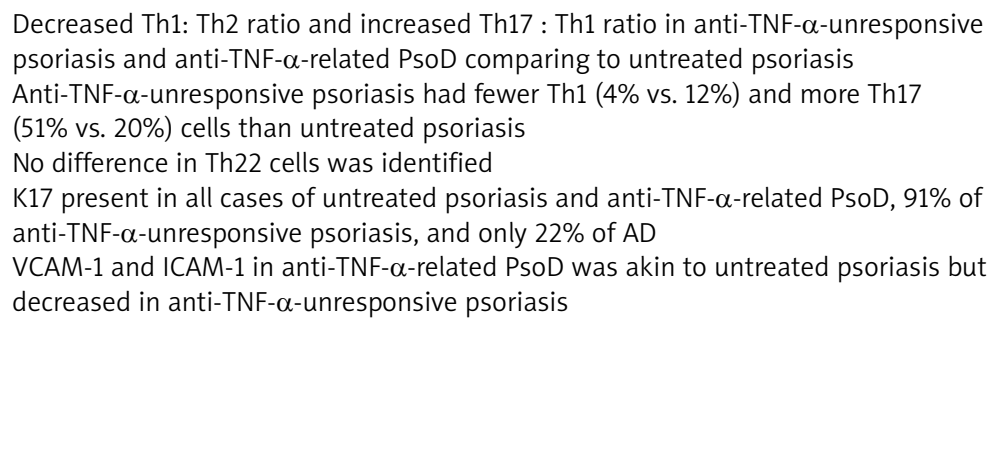 \\
\hline
\end{tabular}


Table 1. Cont.

\begin{tabular}{|c|c|c|}
\hline $\begin{array}{l}\text { Author, year } \\
\text { of publication }\end{array}$ & Material & Main findings \\
\hline $\begin{array}{l}\text { Stoffel et al., } \\
2017 \text { [86] }\end{array}$ & $\begin{array}{l}19 \text { skin biopsies from } \\
\text { inflammatory bowel disease } \\
(n=17) \text { and rheumatoid } \\
\text { arthritis }(n=2) \text { patients with } \\
\text { new-onset inflammatory skin } \\
\text { lesions during anti-TNF- } \alpha- \\
\text { therapy }\end{array}$ & $\begin{array}{l}\text { Conventional psoriasis had the highest levels of IL-17A, IL-17F, IL-19, IL-1B, within } \\
\text { each comparison } \\
\text { Eczema had the highest mRNA expression levels of IL-4, IL-13, IL-9 } \\
\text { Psoriasis form and eczematous lesions showed increases in the pro-inflammatory } \\
\text { mediators: IL-36A, IL-36G, IL-19, and IL-20, as well as the IFN- } \alpha \text { marker Mx1, scalp } \\
\text { lesions lacked upregulation of these mediators } \\
\text { Eczematous lesions showed upregulation of IL-13, IL-5 and showed highest levels of } \\
\text { IL-22 comparing to conventional psoriasis, eczema and anti-TNF- } \alpha \text { lesions } \\
\text { All forms of anti-TNF- } \alpha \text {-induced lesions showed higher increases of IFN- } \gamma \text { and in } \\
\text { IFN- } \gamma \text { regulated molecules such as the IL-12 receptor subunit IL12RB2 comparing to } \\
\text { psoriasis and eczema }\end{array}$ \\
\hline $\begin{array}{l}\text { Dos Santos } \\
\text { et al., } 2017 \\
{[97]}\end{array}$ & $\begin{array}{l}\text { Serum from } 21 \text { patients with } \\
A D \text { and } 21 \text { healthy non-AD } \\
\text { volunteers }\end{array}$ & $\begin{array}{l}\text { Reduced frequency of IFN-c }+ \text { and TNF+ after TLR2 (Pam3CSK4) and TLR7/8 (CL097) } \\
\text { stimuli } \\
\text { Increased frequency of IL-10 under TLR4 (LPS) stimulation in AD individuals } \\
\text { Increased frequency of IL-10 after TLR7/8 (CL097) stimulation in PBMC }\end{array}$ \\
\hline \multirow[t]{2}{*}{$\begin{array}{l}\text { Ovsiy et al. } \\
2017 \text { [98] }\end{array}$} & RAW 264.7 cell line & $\begin{array}{l}\text { Presence of FoxQ1 resulted in significant acceleration of TNF } \alpha \text { secretion } 3 \mathrm{~h} \text { and } 6 \mathrm{~h} \\
\text { after LSP stimuli in RAW } 264.7 \text { cell lines } \\
\text { LSP1 expression was not decreased in monocytes /macrophages stimulated with IL-4 } \\
\text { for } 3 \mathrm{~h} \text { or } 6 \text { days } \\
\text { Significant inhibition of plexin C1 expression found in human monocytes stimulated with } \\
\text { IL-4 for } 3 \mathrm{~h} \text { and in monocyte-derived macrophages differentiated with IL- } 4 \text { for } 6 \text { days }\end{array}$ \\
\hline & $\begin{array}{l}8 \text { patients (18-60 years old) } \\
\text { with clinically proven atopic } \\
\text { dermatitis and high serum } \\
\text { IgE levels } \\
\text { Human peripheral blood } \\
\text { mononuclear cells stimulated } \\
\text { with } 10 \mathrm{ng} / \mathrm{ml} \mathrm{IL-4} \text { and } \\
100 \mathrm{ng} / \mathrm{ml} \mathrm{IFN}-\gamma\end{array}$ & $\begin{array}{l}\text { FoxQ1 expression in macrophages is stimulated by IL-4 (after } 6 \text { days) and suppressed } \\
\text { by IFN- } \gamma \text { in AD patients } \\
\text { Re-stimulation of IL-4-treated macrophages with IFN- } \gamma \text { or LPS resulted in rapid } \\
\text { downregulation of FoxQ1 mRNA expression } \\
3 \mathrm{~h} \text { after the addition of the IL-4 and between } 6 \mathrm{~h} \text { and } 25 \mathrm{~h} \text { of stimulation expression } \\
\text { of FoxQ1 rapidly increased in healthy donors } \\
\text { On the protein level, FoxQ1 was weakly expressed in non-stimulated macrophages } \\
\text { and more pronouncedly in IL- } 4 \text { stimulated monocyte-derived macrophages as } \\
\text { detected by immunofluorescent staining/confocal microscopy on day } 6 \text { of culture }\end{array}$ \\
\hline $\begin{array}{l}\text { Cho et al., } \\
2017 \text { [81] }\end{array}$ & $\begin{array}{l}\text { The frozen stored serum } \\
\text { samples from } 16 \text { adult AD } \\
\text { patients with lgE-mediated } \\
\text { sensitization to HDM }\end{array}$ & $\begin{array}{l}\text { Increased serum level of IL-10 and IFN- } \gamma \text { at } 4,8 \text {, and } 12 \text { weeks compared with } \\
\text { baseline } \\
\text { There were no significant differences in the serum levels of IL-4 or IL-12 before and } \\
\text { after intramuscular administration of autologous total IgG }\end{array}$ \\
\hline \multirow[t]{2}{*}{$\begin{array}{l}\text { Mashiko et al. } \\
2017 \text { [90] }\end{array}$} & $\begin{array}{l}\text { Lesional skin biopsies and } \\
\text { blood collected from AD } \\
\text { patients; } n=12 \text {, psoriasis; } \\
n=11\end{array}$ & $\begin{array}{l}\text { Infiltrating T cells produce IL-4 and IL-13 prior to stimulation in lesional skin of AD } \\
\text { but not psoriasis } \\
\text { Basophils that express IL-4 are detected in lesional skin of AD but not psoriasis and } \\
\text { correlate with skin ILC2 and not blood ILC2 }\end{array}$ \\
\hline & & $\begin{array}{l}\text { T cells from PBMC did not express IL- } 4 \text { and IL-13 } \\
\text { No cytokine was detected in ILCs from freshly isolated PBMC } \\
\text { Basophils from PBMC did not express either cytokine, only IL-4 was increased } \\
\text { following stimulation irrespective of disease examined } \\
\text { IL-4 production by circulating basophils and Th2 cells and IL-13 by ILCs and Th2 cells } \\
\text { was similar in both diseases }\end{array}$ \\
\hline $\begin{array}{l}\text { Sheikhi et al., } \\
2017 \text { [82] }\end{array}$ & $\begin{array}{l}\text { PMBC's from } 20 \text { AD patients } \\
\text { (age 1-12 years) co-cultured } \\
\text { with different concentrations } \\
\text { of UV killed L. Bulgaricus }\end{array}$ & $\begin{array}{l}\text { L. Bulgaricus significantly } \\
\text { - up-regulated the secretion of IL-10, IL-12, and IFN- } \gamma \\
\text { - decreased the secretion of IL- } 4 \\
\text { by PBMCs at both incubation times } 48 \mathrm{~h} / 72 \mathrm{~h} \text { and both bacteria: PBMCs ratios } \\
100: 1 / 50: 1 \text {. } \\
\text { There were no significant differences between incubation times } 48 \mathrm{~h} \text { and } 72 \mathrm{~h} \\
\text { regarding the secretion levels of IL-12, IFN- } \gamma \text {, and IL- } 4 \\
\text { The secretion of IL-10 by L. Bulgaricus-stimulated PBMCs at incubation time } 72 \mathrm{~h} \\
\text { and in the presence of bacteria: PBMCs ratio } 100: 1 \text { was significantly higher than in } \\
\text { incubation time } 48 \mathrm{~h} \text { and in the presence of bacteria: PBMCs ratio } 50: 1\end{array}$ \\
\hline
\end{tabular}


Table 1. Cont.

\begin{tabular}{|c|c|c|}
\hline $\begin{array}{l}\text { Author, year } \\
\text { of publication }\end{array}$ & Material & Main findings \\
\hline $\begin{array}{l}\text { Tyurin et al., } \\
2017[83]\end{array}$ & $\begin{array}{l}\text { The first group composed of } \\
50 \text { individuals ( } 25 \text { people with } \\
\text { atopic dermatitis and } 25 \text { with } \\
\text { atopic dermatitis combined } \\
\text { with either allergic rhinitis or } \\
\text { allergic bronchial asthma) } \\
\text { The control group consisted } \\
\text { of } 100 \text { persons (medical } \\
\text { personnel) without symptoms } \\
\text { of atopic dermatitis }\end{array}$ & $\begin{array}{l}\text { The group of patients having the heterozygous genotype for the TLR2 receptor had: } \\
\text { - significant reduction in serum levels of INF- } \gamma \text { ( } 1.5 \text { times lower) } \\
\text { - increase in the levels of IL- } 4 \text { and IL-10 (1.4 and } 1.8 \text { times higher) } \\
\text { The heterozygous group for the TLR4 receptor had: } \\
\text { - significant reduction in serum levels of INF- } \gamma \text { (1.6 times lower) } \\
\text { - significant increase in the concentrations of serum interleukins IL-4 and IL-10 } \\
\text { (1.3 and } 1.6 \text { times higher) } \\
\text { Serum levels of INF- } \gamma \text { significantly decreased (1.4 times lower) in patients with AD } \\
\text { Serum levels of IL-4 and IL-10 were } 1.6 \text { times higher but only in the groups of sick } \\
\text { individuals with heterozygous genotypes for both receptors } \\
\text { No significant differences were detected in healthy individuals for the serum levels } \\
\text { of cytokines depending on the genotype }\end{array}$ \\
\hline $\begin{array}{l}\text { Czarnowicki } \\
\text { et al., } 2017 \\
{[91]}\end{array}$ & $\begin{array}{l}\text { Peripheral blood from } \\
32 \text { moderate-to-severe } \\
\text { alopecia areata }(A A) \text { adults } \\
\text { with } 43 \text { moderate-to-severe } \\
\text { AD patients and } 30 \text { age- } \\
\text { matched controls }\end{array}$ & $\begin{array}{l}\text { IL-13 frequencies were significantly higher in } A D \\
\text { IFN- } \gamma \text { levels were mostly similar in } A A, A D \text { patients, and controls }\end{array}$ \\
\hline $\begin{array}{l}\text { Guttman- } \\
\text { Yassky et al., } \\
2017[85]\end{array}$ & $\begin{array}{l}\text { Biopsied lesions from } \\
30 \text { adult patients ( } 16 \text { male } \\
\text { and } 14 \text { female patients) with } \\
\text { mild-to-moderate AD }\end{array}$ & $\begin{array}{l}\text { IL-13, and IL-22 were similarly reduced only by steroids } \\
\text { Both steroids showed similar improvements, and only a few markers (including IL-5) } \\
\text { showed larger reductions with clobetasol }\end{array}$ \\
\hline $\begin{array}{l}\text { Brunner et al., } \\
2017 \text { [87] }\end{array}$ & $\begin{array}{l}29 \text { lesional and } 19 \text { non- } \\
\text { lesional AD biopsies, } \\
\text { compared to } 6 \text { healthy control }\end{array}$ & $\begin{array}{l}\text { Lesional T-cell fractions correlated with IL-13, IL-23p19, and IL-21 responses } \\
\text { Neither T-cell fraction nor clonality levels correlated with serum IgE or SCORAD }\end{array}$ \\
\hline $\begin{array}{l}\text { Nygaard } \\
\text { et al., } 2018 \\
{[86]}\end{array}$ & $\begin{array}{l}\text { Serum from } 71 \text { adults and } \\
61 \text { children with } A D \text { and } \\
31 \text { adult controls }\end{array}$ & $\begin{array}{l}\text { Serum levels of IL-31 and IL-33 were significantly elevated in AD patients compared } \\
\text { with controls } \\
\text { In AD patients, both IL-31 and IL-33 serum levels were higher in children than in } \\
\text { adults } \\
\text { We observed no correlation between disease severity and any of the investigated } \\
\text { cytokines } \\
\text { Serum levels of IL-31 and IL-33 were affected to a small extent }\end{array}$ \\
\hline $\begin{array}{l}\text { Esaki et al., } \\
2017[88]\end{array}$ & $\begin{array}{l}\text { Biopsy specimens from } \\
19 \text { children with } A D \\
\text { younger than } 5 \text { years within } \\
6 \text { months of disease onset in } \\
\text { comparison with adults with } \\
\text { AD or psoriasis and paediatric } \\
\text { and adult control subjects }\end{array}$ & $\begin{array}{l}\text { In lesional skin children showed comparable to adults, strong activation of IL-13, } \\
\text { IL-31 and IL-22 axes and IFN- } \gamma \text { was present } \\
\text { Children showed significantly higher induction of IL-17A, IL-19, IL-9, IL-33, and IL-8 } \\
\text { than adults } \\
\text { Nonlesional skin in children with AD showed higher levels of IL-17A and IL-19 and } \\
\text { epidermal proliferation markers }\end{array}$ \\
\hline $\begin{array}{l}\text { Nattkemper } \\
\text { et al., } 2017 \\
\text { [93] }\end{array}$ & $\begin{array}{l}\text { Skin from paired itchy, } \\
\text { lesional and non-itchy, non- } \\
\text { lesional skin biopsies from } \\
25 \text { atopic dermatitis (AD) and } \\
25 \text { psoriasis patients and site- } \\
\text { matched biopsies from } \\
30 \text { healthy controls }\end{array}$ & $\begin{array}{l}\text { Cytokines such as IL-17A, IL-23A, and IL-31 had elevated gene transcript levels in } \\
\text { both itchy atopic and psoriatic skin } \\
\text { Expression of genes for IL-10 was found to be increased only in pruritic atopic skin, } \\
\text { while expression of genes for IL-36 } \alpha / \gamma \text { was elevated only in pruritic psoriatic skin }\end{array}$ \\
\hline $\begin{array}{l}\text { Martel et al., } \\
2017[94]\end{array}$ & $\begin{array}{l}\text { Skin biopsies from patients } \\
\text { with extrinsic } A D(n=6) \text {, } \\
\text { intrinsic } A D(n=9) \text { and } \\
\text { psoriasis }(n=9)\end{array}$ & $\begin{array}{l}\text { Few cells were found to be positive for IL-17 and its transcription factor RORct } \\
\text { No significant difference detected for any of the other measured transcription } \\
\text { factors or cytokines either intracellularly or in the supernatant } \\
\text { IL-9, IL-12, IL-21, IL-25, IL17A, IL-17F, and IL-33 could not be quantified in the } \\
\text { supernatants of any culture } \\
\text { IL-22 was only quantifiable in media from a single extrinsic AD culture and IL-31 } \\
\text { in two intrinsic AD cultures, and these cytokines were not detected in any of the } \\
\text { psoriatic cultures } \\
\text { No differences found in the cytokine profile of T cell cultures derived from extrinsic } \\
\text { AD and intrinsic AD skin }\end{array}$ \\
\hline
\end{tabular}


Table 1. Cont.

\begin{tabular}{|c|c|c|}
\hline $\begin{array}{l}\text { Author, year } \\
\text { of publication }\end{array}$ & Material & Main findings \\
\hline $\begin{array}{l}\text { Bernard et al., } \\
2017 \text { [99] }\end{array}$ & $\begin{array}{l}\text { Reconstructed human } \\
\text { epidermis (RHE) from } \\
\text { keratinocytes of the outer } \\
\text { root sheath of hair follicles } \\
12 \text { healthy individuals and } \\
7 \text { AD patients }\end{array}$ &  \\
\hline $\begin{array}{l}\text { Sgnotto et al. } \\
2018 \text { [92] }\end{array}$ & $\begin{array}{l}\text { Thymic tissues obtained from } \\
14 \text { patients who underwent } \\
\text { corrective cardiac surgery } \\
\text { Blood samples were collected } \\
\text { from } 10 \text { subjects who were } \\
\text { previously clinically classified as } \\
\text { having moderate or severe AD }\end{array}$ & $\begin{array}{l}\text { TDP cells cultured with purified IgG from AD patients, and TDP cells produced higher } \\
\text { levels of IL-17A, IL-10, and TGF- } \beta \text { compared to the levels in both mock and IVIG- } \\
\text { treated cells } \\
\text { Higher production of IL-17A and IL-10 in TCD4 cell population after culture with AD } \\
\text { IgG compared to mock and IVIg-treated conditions } \\
\text { Higher levels of IL-17A, TNF- } \alpha \text {, IL-10, and TGF- } \beta \text { in TCD8 cell population, compared to } \\
\text { the mock and IVIG-treated conditions }\end{array}$ \\
\hline $\begin{array}{l}\text { Zhu et al., } \\
2017 \text { [100] }\end{array}$ & $\begin{array}{l}\text { Skin biopsies were taken from } \\
\text { nonlesional and lesional skin } \\
\text { from } 5 \text { AD patients }\end{array}$ & $\begin{array}{l}\text { Upregulated KLK5 stimulated secretion of IL- } 8 \text { and IL-10 } \\
\text { With control of higher KLK5 activity by the inhibitor sunflower trypsin inhibitor G } \\
\text { reduction in AD-related cytokine IL- } 8 \text { and IL-10 secretion were observed. }\end{array}$ \\
\hline $\begin{array}{l}\text { Malik et al., } \\
2017 \text { [101] }\end{array}$ & $\begin{array}{l}\text { Biopsied lesions from } \\
30 \text { patients, } 15 \text { with positive } \\
\text { house dust mite responses }\end{array}$ & $\begin{array}{l}\text { HDM showed greater and more significant inflammation, including higher } \\
\text { upregulation of markers related to general inflammation, IL-9, IL-22, and IL-19 vs. AD } \\
\text { Both HDM and AD lesions showed significant upregulation of Th2 markers, some Th2 } \\
\text { products were not as highly upregulated by HDM compared to chronic AD lesions } \\
\text { IL-4, IL-10, IL-31, and IL-33, were not significantly upregulated in HDM APT responses } \\
\text { vs. healthy skin, whereas the majority of these markers were significantly upregulated } \\
\text { in AD lesions } \\
\text { Th17-related markers (IL-8, IL-23p40) were strongly upregulated in HMD tissues } \\
\text { showing greater similarity to nickel responses rather than to AD lesions, which } \\
\text { showed lesser Th-17 skewing } \\
\text { IL-22, and the IL-17/IL-22-induced S100As were significantly elevated in HDM tissues } \\
\text { vs. controls, similar to AD lesions and nickel responses } \\
\text { In AD patients, HDM showed greater immune activation across all inflammatory axes } \\
\text { (IL-9, IL-22) } \\
\text { IL-13, CCL22 and the Treg product FOXp3 showed more significant upregulation in } \\
\text { healthy individuals } \\
\text { Pathway enrichment analysis of the HDM transcriptome: } \\
\text { - some were common to AD and psoriasis (T-cell receptor, NOD and toll-like receptor } \\
\text { signaling, JAK-STAT signaling, interferon } \gamma \text { signaling), Th22 (IL-22) } \\
\text { - specific to psoriasis (neutrophil, Th17 (IL-17, IL-12/23), tryptophan catabolism) } \\
\text { - specific to AD [Th2 (IL-4), FCERI signaling] }\end{array}$ \\
\hline $\begin{array}{l}\text { Tan et al., } \\
2017 \text { [102] }\end{array}$ & $\begin{array}{l}\text { Peripheral blood samples } \\
\text { were collected from } \\
87 \text { children with AD and } \\
60 \text { healthy children as control } \\
\text { subjects }\end{array}$ & $\begin{array}{l}\text { The frequency of IL-17+ cells was higher in the dermis of patients with AD } \\
\text { Serum IL-17 levels were higher in the AD group }(10.47 \pm 3.39 \mathrm{pg} / \mathrm{ml}) \text { compared } \\
\text { with the control group }(9.63 \pm 3.36 \mathrm{pg} / \mathrm{ml}) \text {, but this difference was not statistically } \\
\text { significant }\end{array}$ \\
\hline
\end{tabular}

a quarter of the patients with $A D$ have been diagnosed with a mutation in the filaggrin gene. It is clear now that the pathophysiological concepts underlying the development of $A D$ are multi-factorial.

Atopic dermatitis research would strongly benefit from the unification of research methodology. General outlines systemizing material and methodology in AD research would contribute to the generation of high-quality data and publications that could be later analysed as a whole. This approach could accelerate the creation of new medical therapies and strategies.

\section{Conflict of interest}

The authors declare no conflict of interest.

\section{References}

1. Novak N, Leung DYM. Advances in atopic dermatitis. Curr Opin Immunol 2011; 23: 778-83.

2. Bieber T. Atopic dermatitis. Ann Dermatol 2010; 22: 125-37.

3. Boguniewicz M, Abramovits W, Paller A, et al. A multiple-domain framework of clinical, economic, and patient-reported outcomes for evaluating benefits of intervention in atopic dermatitis. J Drugs Dermatol 2007; 6: 416-23. 
4. Mancini AJ, Kaulback K, Chamlin SL. The socioeconomic impact of atopic dermatitis in the United States: a systematic review. Pediatr Dermatol 2008; 25: 1-6.

5. Cevikbas F, Wang X, Akiyama T, et al. A sensory neuronexpressed IL-31 receptor mediates T helper cell-dependent itch: Involvement of TRPV1 and TRPA1. J Allergy Clin Immunol 2014; 133: 448-60.

6. Wollina U. Microbiome in atopic dermatitis. Clin Cosmet Investig Dermatol 2017; 10: 51-6.

7. Thyssen JP, Kezic S. Causes of epidermal filaggrin reduction and their role in the pathogenesis of atopic dermatitis. J Allergy Clin Immunol 2014; 134: 792-9.

8. Lesiak A, Kuna P, Zakrzewski M, et al. Combined occurrence of filaggrin mutations and IL-10 or IL-13 polymorphisms predisposes to atopic dermatitis. Exp Dermatol 2011; 20: 491-5.

9. Meng L, Wang L, Tang H, et al. Filaggrin gene mutation c.3321delA is associated with various clinical features of atopic dermatitis in the Chinese Han ppulation. PLoS One 2014; 9: e98235.

10. Morar N, Cookson WOCM, Harper JI, Moffatt MF. Filaggrin mutations in children with severe atopic dermatitis. J Invest Dermatol 2007; 127: 1667-72.

11. Carson CG, Rasmussen MA, Thyssen JP, et al. Clinical presentation of atopic dermatitis by filaggrin gene mutation status during the first 7 years of life in a prospective cohort study. PLoS One 2012; 7: e48678.

12. Nutten S. Atopic dermatitis: global epidemiology and risk factors. Ann Nutr Metab 2015; 66: 8-16.

13. Brown SJ, Irvine AD. Atopic eczema and the filaggrin story. Semin Cutan Med Surg 2008; 27: 128-37.

14. Hammad H, Lambrecht BN. Barrier epithelial cells and the control of type 2 immunity. Immunity 2015; 43: 29-40.

15. Boguniewicz M, Leung DY. Atopic dermatitis: a disease of altered skin barrier and immune dysregulation. Immunol Rev 2011; 242: 233-46.

16. Wüthrich B, Schmid-Grendelmeier P. The atopic eczema/dermatitis syndrome. Epidemiology, natural course, and immunology of the IgE-associated ("extrinsic") and the nonallergic ("intrinsic") AEDS. I Investig Allergol Clin Immunol 2003; 13: 1-5.

17. Wollenberg A, Kraft S, Hanau D, Bieber T. Immunomorphological and ultrastructural characterization of Langerhans cells and a novel, inflammatory dendritic epidermal cell (IDEC) population in lesional skin of atopic eczema. J Invest Dermatol 1996; 106: 446-53.

18. Novak N, Bieber T. The role of dendritic cell subtypes in the pathophysiology of atopic dermatitis. J Am Acad Dermatol 2005; 53: S171-6.

19. Hamid Q, Boguniewicz M, Leung DY. Differential in situ cytokine gene expression in acute versus chronic atopic dermatitis. J Clin Invest 1994; 94: 870-6.

20. Trautmann A, Akdis M, Kleemann D, et al. T cell-mediated Fas-induced keratinocyte apoptosis plays a key pathogenetic role in eczematous dermatitis. J Clin Invest 2000; 106: 25-35.

21. Toda M, Leung DYM, Molet S, et al. Polarized in vivo expression of IL-11 and IL-17 between acute and chronic skin lesions. J Allergy Clin Immunol 2003; 111: 875-81.

22. Eyerich K, Pennino D, Scarponi C, et al. IL-17 in atopic eczema: linking allergen-specific adaptive and microbial-triggered innate immune response. J Allergy Clin Immunol 2009; 123: 59-66.e4.

23. Nakayama T, Fujisawa R, Yamada $\mathrm{H}$, et al. Inducible expression of a CC chemokine liver- and activation-regulated chemokine (LARC)/macrophage inflammatory protein (MIP)-3
alpha/CCL20 by epidermal keratinocytes and its role in atopic dermatitis. Int Immunol 2001; 13: 95-103.

24. Schön MP, Zollner TM, Boehncke WH. The molecular basis of lymphocyte recruitment to the skin: clues for pathogenesis and selective therapies of inflammatory disorders. J Invest Dermatol 2003; 121: 951-62.

25. Wilson NS, Dixit V, Ashkenazi A. Death receptor signal transducers: nodes of coordination in immune signaling networks. Nat Immunol 2009; 10: 348-55.

26. Youle RJ, Strasser A. The BCL-2 protein family: opposing activities that mediate cell death. Nat Rev Mol Cell Biol 2008; 9: 47-59.

27. Houben E, De Paepe K, Rogiers V. A keratinocyte's course of life. Skin Pharmacol Physiol 2007; 20: 122-32.

28. Lee SH, Jang JJ, Lee JY, et al. Fas ligand is expressed in normal skin and in some cutaneous malignancies. Br J Dermatol 1998; 139: 186-91.

29. Boehm I. Apoptosis in physiological and pathological skin: implications for therapy. Curr Mol Med 2006; 6: 375-94.

30. Zimmermann M, Koreck A, Meyer N, et al. TNF-like weak inducer of apoptosis (TWEAK) and TNF- $\alpha$ cooperate in the induction of keratinocyte apoptosis. J Allergy Clin Immunol 2011; 127: 200-7, 207.e1-10.

31. Rebane A, Zimmermann M, Aab A, et al. Mechanisms of IFNgamma-induced apoptosis of human skin keratinocytes in patients with atopic dermatitis. J Allergy Clin Immunol 2012; 129: 1297-306.

32. Wajant H, Pfizenmaier K, Scheurich P. Non-apoptotic Fas signaling. Cytokine Growth Factor Rev 2003; 14: 53-66.

33. Farley SM, Dotson AD, Purdy DE, et al. Fas ligand elicits a caspase-independent proinflammatory response in human keratinocytes: implications for dermatitis. J Invest Dermatol 2006; 126: 2438-51.

34. Farley SM, Purdy DE, Ryabinina OP, et al. Fas ligand-induced proinflammatory transcriptional responses in reconstructed human epidermis. Recruitment of the epidermal growth factor receptor and activation of MAP kinases. J Biol Chem 2008; 283: 919-28.

35. Krzyzowska M, Shestakov A, Eriksson K, Chiodi F. Role of Fas/ FasL in regulation of inflammation in vaginal tissue during HSV-2 infection. Cell Death Dis 2011; 2: e132.

36. Krzyżowska M, Winnicka A, Stankiewicz W. HSV-2-infected monocytes and keratinocytes show different inflammatory reaction in response to Fas receptor stimulation. Cent Eur J Immunol 2013; 38: 196-202.

37. De Benedictis FM, Franceschini F, Hill D, et al. The allergic sensitization in infants with atopic eczema from different countries. Allergy 2009; 64: 295-303.

38. Leung DYM, Boguniewicz M, Howell MD, et al. New insights into atopic dermatitis. J Clin Invest 2004; 113: 651-7.

39. Trinchieri G. Interleukin-12 and the regulation of innate resistance and adaptive immunity. Nat Rev Immunol 2003; 3: 133-46.

40. Köck A, Schwarz T, Kirnbauer R, et al. Human keratinocytes are a source for tumor necrosis factor alpha: evidence for synthesis and release upon stimulation with endotoxin or ultraviolet light. J Exp Med 1990; 172: 1609-14.

41. Wajant H, Pfizenmaier K, Scheurich P. Tumor necrosis factor signaling. Cell Death Differ 2003; 10: 45-65.

42. Liu H, Sidiropoulos P, Song G, et al. TNF-alpha gene expression in macrophages: regulation by NF-kappa $B$ is independent of c-Jun or C/EBP beta. J Immunol Baltim Md 1950. 2000; 164: 4277-85. 
43. Danso MO, van Drongelen V, Mulder A, et al. TNF- $\alpha$ and Th2 cytokines induce atopic dermatitis-like features on epiderma differentiation proteins and stratum corneum lipids in human skin equivalents. J Invest Dermatol 2014; 134: 1941-50.

44. Shiraki Y, Ishibashi Y, Hiruma M, et al. Cytokine secretion profiles of human keratinocytes during Trichophyton tonsurans and Arthroderma benhamiae infections. J Med Microbiol 2006; 55: 1175-85.

45. Jeong CW, Ahn KS, Rho NK, et al. Differential in vivo cytokine mRNA expression in lesional skin of intrinsic vs. extrinsic atopic dermatitis patients using semiquantitative RT-PCR. Clin Exp Allergy J Br Soc Allergy Clin Immunol 2003; 33: 1717-24.

46. Sehra S, Yao Y, Howell MD, et al. IL-4 regulates skin homeostasis and the predisposition toward allergic skin inflammation. J Immunol Baltim Md 1950 2010; 184: 3186-90.

47. Tazawa T, Sugiura H, Sugiura Y, Uehara M. Relative importance of IL-4 and IL-13 in lesional skin of atopic dermatitis. Arch Dermatol Res 2004; 295: 459-64.

48. Wynn TA. IL-13 effector functions. Annu Rev Immunol 2003; 21: $425-56$

49. Nedoszytko B, Sokołowska-Wojdyło M, RuckemannDziurdzińska K, et al. Chemokines and cytokines network in the pathogenesis of the inflammatory skin diseases: atopic dermatitis, psoriasis and skin mastocytosis. Adv Dermatol Allergol 2014; 31: 84-91.

50. Hamid Q, Naseer T, Minshall EM, et al. In vivo expression of IL-12 and IL-13 in atopic dermatitis. J Allergy Clin Immunol 1996; 98: 225-31.

51. Biedermann T, Skabytska Y, Kaesler S, Volz T. Regulation of T cell immunity in atopic dermatitis by microbes: the yin and yang of cutaneous inflammation. Front Immunol [Internet] 2015 [cited 2016 Nov 27]; 6. Available from: http://journal. frontiersin.org/article/10.3389/fimmu.2015.00353/abstract

52. Sonkoly E, Muller A, Lauerma Al, et al. IL-31: a new link between T cells and pruritus in atopic skin inflammation. J Allergy Clin Immunol 2006; 117: 411-7.

53. Zhang Q, Putheti P, Zhou Q, et al. Structures and biological functions of IL-31 and IL-31 receptors. Cytokine Growth Factor Rev 2008; 19: 347-56.

54. Barksby HE, Lea SR, Preshaw PM, Taylor JJ. The expanding family of interleukin-1 cytokines and their role in destructive inflammatory disorders. Clin Exp Immunol 2007; 149: 217-25.

55. Abramovits W, Rivas Bejarano JJ, Valdecantos WC. Role of interleukin 1 in atopic dermatitis. Dermatol Clin 2013; 31: 437-44

56. Asadullah K, Sterry W, Volk HD. Interleukin-10 therapy - review of a new approach. Pharmacol Rev 2003; 55: 241-69.

57. Ohmen JD, Hanifin JM, Nickoloff BJ, et al. Overexpression of IL-10 in atopic dermatitis. Contrasting cytokine patterns with delayed-type hypersensitivity reactions. J Immuno 1995; 154: 1956-63.

58. Harada A, Sekido N, Akahoshi T, et al. Essential involvement of interleukin-8 (IL-8) in acute inflammation. J Leukoc Biol 1994; 56: 559-64.

59. Sekine C, Yagita H, Kobata T, et al. Fas-mediated stimulation induces IL-8 secretion by rheumatoid arthritis synoviocytes independently of CPP32-mediated apoptosis. Biochem Biophys Res Commun 1996; 228: 14-20.

60. Brat DJ, Bellail AC, Van Meir EG. The role of interleukin-8 and its receptors in gliomagenesis and tumoral angiogenesis. Neuro Oncol 2005; 7: 122-33.

61. Korn T, Bettelli E, Oukka M, Kuchroo VK. IL-17 and Th17 cells. Annu Rev Immunol 2009; 27: 485-517.
62. Wu L, Chen X, Zhao J, et al. A novel IL-17 signaling pathway controlling keratinocyte proliferation and tumorigenesis via the TRAF4-ERK5 axis. J Exp Med 2015; 212: 1571-87.

63. Nograles KE, Suárez-Farińas M, Shemer A, et al. Atopic dermatitis (AD) keratinocytes exhibit normal Th17 cytokine responses. J Allergy Clin Immunol 2010; 125: 744-6.e2.

64. Dhingra N, Guttman-Yassky E. A possible role for IL-17A in establishing Th2 inflammation in murine models of atopic dermatitis. J Invest Dermatol 2014; 134: 2071-4.

65. Weaver CT, Hatton RD, Mangan PR, Harrington LE. IL-17 family cytokines and the expanding diversity of effector $T$ cell lineages. Annu Rev Immunol 2007; 25: 821-52.

66. Moussion C, Ortega N, Girard JP. The IL-1-like cytokine il-33 is constitutively expressed in the nucleus of endothelial cells and epithelial cells in vivo: a novel 'alarmin'? PLOS One 2008; 3: e3331.

67. Pichery M, Mirey E, Mercier P, et al. Endogenous IL-33 is highly expressed in mouse epithelial barrier tissues, lymphoid organs, brain, embryos, and inflamed tissues: in situ analysis using a novel II-33-LacZ gene trap reporter strain. J Immunol Baltim Md 1950 2012; 188: 3488-95.

68. Cayrol C, Girard JP. IL-33: an alarmin cytokine with crucial roles in innate immunity, inflammation and allergy. Curr Opin Immunol 2014; 31: 31-7.

69. Molofsky AB, Savage A, Locksley RM. Interleukin-33 in tissue homeostasis, injury and inflammation. Immunity 2015; 42: 1005-19.

70. Schmitz J, Owyang A, Oldham E, et al. IL-33, an interleukin1-like cytokine that signals via the IL-1 receptor-related protein ST2 and induces T helper type 2-associated cytokines. Immunity 2005; 23: 479-90.

71. Savinko T, Matikainen S, Saarialho-Kere U, et al. IL-33 and ST2 in atopic dermatitis: expression profiles and modulation by triggering factors. J Invest Dermatol 2012; 132: 1392-400.

72. Chen YL, Gutowska-Owsiak D, Hardman CS, et al. Proof-ofconcept clinical trial of etokimab shows a key role for IL-33 in atopic dermatitis pathogenesis. Sci Transl Med 2019; 11: eaax2945.

73. Gallagher G, Dickensheets H, Eskdale J, et al. Cloning, expression and initial characterization of interleukin-19 (IL-19), a novel homologue of human interleukin-10 (IL-10). Genes Immun 2000; 1: 442-50.

74. Bao L, Alexander JB, Shi VY, et al. Interleukin-4 up-regulation of epidermal interleukin-19 expression in keratinocytes involves the binding of signal transducer and activator of transcription 6 (Stat6) to the imperfect Stat6 sites. Immunology 2014; 143: 601-8

75. Huang F, Wachi S, Thai P, et al. Potentiation of IL-19 expression in airway epithelia by IL-17A and IL-4/IL-13: important implications in asthma. J Allergy Clin Immunol 2008; 121: 1415-21, 1421.e1-3.

76. Dumoutier L, Leemans C, Lejeune D, et al. Cutting edge: STAT activation by IL-19, IL-20 and mda-7 through IL-20 receptor complexes of two types. J Immunol Baltim Md 1950 2001; 167: 3545-9.

77. Wang M, Tan Z, Zhang R, et al. Interleukin 24 (MDA-7/MOB-5) signals through two heterodimeric receptors, IL-22R1/ IL-20R2 and IL-20R1/IL-20R2. J Biol Chem 2002; 277: 7341-7.

78. Witte E, Kokolakis G, Witte K, et al. IL-19 is a component of the pathogenetic IL-23/IL-17 cascade in psoriasis. J Invest Dermatol 2014; 134: 2757-67.

79. Orciani M, Campanati A, Caffarini M, et al. T helper (Th)1, Th17 and Th2 imbalance in mesenchymal stem cells of adult 
patients with atopic dermatitis: at the origin of the problem. Br J Dermatol 2016; 176: 1569-76.

80. Yang Z, Zeng B, Wang C, et al. MicroRNA-124 alleviates chronic skin inflammation in atopic eczema via suppressing innate immune responses in keratinocytes. Cell Immunol 2017; 319: 53-60.

81. Cho SM, Kim ME, Kwon B, Nahm DH. Immunomodulatory effects induced by intramuscular administration of autologous total immunoglobulin $\mathrm{G}$ in patients with atopic dermatitis. Int Immunopharmacol 2017; 52: 1-6.

82. Sheikhi A, Giti H, Heibor MR, et al. Lactobacilus Delbrueckii subsp. Bulgaricus modulates the secretion of Th1/Th2 and Treg cell-related cytokines by PBMCs from patients with atopic dermatitis. Drug Res 2017; 67: 724-9.

83. Tyurin YA, Shamsutdinov AF, Kalinin NN, et al. Association of Toll-like cell receptors TLR2 (p.Arg753GLN) and TLR4 (p.Asp299GLY) polymorphisms with indicators of general and local immunity in patients with atopic dermatitis [Internet]. J Immunol Res 2017 [cited 2018 Apr 6]. Available from: https://www.hindawi.com/journals/jir/2017/8493545/

84. Brunner PM, Suárez-Farińas M, He H, et al. The atopic dermatitis blood signature is characterized by increases in inflammatory and cardiovascular risk proteins. Sci Rep 2017; 7: 8707.

85. Guttman-Yassky E, Ungar B, Malik K, et al. Molecular signatures order the potency of topically applied anti-inflammatory drugs in patients with atopic dermatitis. J Allergy Clin Immunol 2017; 140: 1032-42.e13.

86. Stoffel E, Maier H, Riedl E, et al. Analysis of anti-tumour necrosis factor-induced skin lesions reveals strong T helper 1 activation with some distinct immunological characteristics. Br J Dermatol [Internet]. 2017 [cited 2018 Apr 6];0. Available from: https://onlinelibrary.wiley.com/doi/abs/10.1111/ bjd.16126.

87. Brunner PM, Emerson RO, Tipton C, et al. Nonlesional atopic dermatitis skin shares similar T-cell clones with lesional tissues. Allergy 2017; 72: 2017-25.

88. Esaki H, Brunner PM, Renert-Yuval Y, et al. Early-onset pediatric atopic dermatitis is Th2 but also Th17 polarized in skin. J Allergy Clin Immunol 2016; 138: 1639-51.

89. Weiss D, Schaschinger M, Ristl R, et al. Ustekinumab treatment in severe atopic dermatitis: down-regulation of T-helper 2/22 expression. J Am Acad Dermatol 2017; 76: 91-7.e3.

90. Mashiko S, Mehta H, Bissonnette R, Sarfati M. Increased frequencies of basophils, type 2 innate lymphoid cells and Th2 cells in skin of patients with atopic dermatitis but not psoriasis. J Dermatol Sci 2017; 88: 167-74.

91. Czarnowicki T, He HY, Wen HC, et al. Alopecia areata is characterized by expansion of circulating Th2/Tc2/Th22, within the skin-homing and systemic T-cell populations. Allergy 2018; 73: 713-23.

92. Sgnotto Fábio DR, Oliveira Marilia G, Lira Aline AL, et al. IgG from atopic dermatitis patients induces IL-17 and IL-10 production in infant intrathymic TCD4 and TCD8 cells. Int J Dermatol 2018; 57: 434-40.

93. Nattkemper LA, Tey HL, Valdes-Rodriguez R, et al. The genetics of chronic itch: gene expression in the skin of patients with atopic dermatitis and psoriasis with severe itch. J Invest Dermatol 2018; 138: 1311-7.

94. Martel BC, Dyring-Andersen B, Skov L, et al. Different cytokine profiles of skin-derived T cell cultures from patients with atopic dermatitis and psoriasis. Inflamm Res 2016; 65: 265-72.
95. Chen XF, Zhang LJ, Zhang J, et al. MiR-151a is involved in the pathogenesis of atopic dermatitis by regulating interleukin-12 receptor 32 . Exp Dermatol 2018; 27: 427-32.

96. Moy AP, Murali M, Kroshinsky D, et al. T-helper immune phenotype may underlie 'paradoxical' tumour necrosis factor- $\alpha$ inhibitor therapy-related psoriasiform dermatitis. Clin Exp Dermatol 2018; 43: 19-26.

97. Dos Santos VG, Orfali RL, de Oliveira Titz T, et al. Evidence of regulatory myeloid dendritic cells and circulating inflammatory epidermal dendritic cells-like modulated by Tolllike receptors 2 and $7 / 8$ in adults with atopic dermatitis. Int J Dermatol 2017; 56: 630-5.

98. Ovsiy I, Riabov V, Manousaridis I, et al. IL-4 driven transcription factor FoxQ1 is expressed by monocytes in atopic dermatitis and stimulates monocyte migration. Sci Rep 2017; 7: 16847.

99. Bernard M, Carrasco C, Laoubi L, et al. IL-1 induces thymic stromal lymphopoietin and an atopic dermatitis-like phenotype in reconstructed healthy human epidermis. J Pathol 2017; 242: 234-45.

100. Zhu Y, Underwood J, Macmillan D, et al. Persistent kallikrein 5 activation induces atopic dermatitis-like skin architecture independent of PAR2 activity. J Allergy Clin Immunol 2017; 140: 1310-22.

101. Malik K, Ungar B, Garcet S, et al. Dust mite induces multiple polar T cell axes in human skin. Clin Exp Allergy 2017; 47: 1648-60.

102. Tan O, Yang H, Liu EM, Wang H. Establishing a role for interleukin-17 in atopic dermatitis-related skin inflammation. J Cutan Med Surg 2017; 21: 308-15. 